\title{
日本人及び日米混血兒乳药の研究*
}

\section{IV. 上顎乳的莝について}

\author{
埴 原 和 郎
}

本篇は上顎孚臼齒に關する記載である。前 3 篇と同樣に主として日本人兒童の正常形質に ついて記載し、同時にこれと白系及び黑系混血兒との此較を行つた。材料が石膏印象である ために觀察は荬冠の咬面、頓側面及び舌侧面に限られる。

\section{研究材料及び記號}

本篇で用いた材料は純日本人兒童 118 , 白系混血兒 71 , 黑系混血兒 38 個體である（第 1 表)。これらの大部分は前篇で用いたものと同じであるが、混血兒の中には數個體の新しい標

Table 1. Materials.

\begin{tabular}{|c|r|c|c|}
\hline Sex & J & W & N \\
\hline$\hat{0}$ & 54 & 49 & 17 \\
ㅇ & 64 & 22 & 21 \\
o+ + + & 118 & 71 & 38 \\
\hline
\end{tabular}

本が加觉られた。その年齡は 3 〜 6 才である。

本稿中の記號も前篇におけると同樣であるから解說は 省略する。詳しくは第 1 篇を參照して頂きたいが、各兒 童群に對する略號のみを擧げれば次の通りである。 純日本人兒童群一J, 白系混血兒群一W, 黑系混血兒群 $-\mathrm{N}$.

計測

本䂰究に用いた材料はすべて石高印象であるために計測しうる項目は極めて制限される。 從つてここでとり扱うのは齒䓕の近遠心徑、煩舌徑及び長幅示數のみであり、高徑は不正確 になるのでふれないことにする。これらの值は原則として右側齒のものである。

各統計量の訃算は前篇と同樣に推計學的方法によつたが、比較の便宜のために表には標準 编差も併記した。

1. 近遠心俓。この計测は齒冠長軸に本行に最大徑をとる。

$\mathrm{J}$ 及び $\mathrm{W}$ では性差は認められないが、 $\mathrm{N}$ では $\mathrm{m}^{1} ， \mathrm{~m}^{2}$ 共に著しい差が存在する。檢定 の結果 $\mathrm{m}^{1}$ では $5 \%$ 、 $\mathrm{m}^{2}$ では $1 \%$ の危險率でこの差は有意であるといえる。 $\mathrm{N}$ の性差が著 しいという事賽は下顎乳臼蹈と全く同樣である (第 2,3 表)。

各群を比較すると J と $\mathrm{W}$ との間にはほとんぞ差がないが $\mathrm{N}$ はこの 2 群に比較して極め て大さい。推計學的には $\mathrm{m}^{1}$ に拉いて $\mathrm{J}$ と $\mathrm{N}, \mathrm{W}$ と $\mathrm{N}, \mathrm{m}^{2}$ に和いて $\mathrm{W}$ と $\mathrm{N}$ との間に 有意差が認められる(第 4 表)。

化石人類の上顎乳传齒は極めて少ないが、Mt. Carmel (Tabūn type, $\mathrm{m}^{2}$ 9.0-9.2 mm, MCCown \& KeITH, ’49) は現代人よりかなり大きな值を示している。

2. 煩甹徑。瓷冠長軸と直角の方向に最大徝を計測する。

性差は $\mathrm{J}$ では認められないが $\mathrm{W}$ 及び $\mathrm{N}$ には明らかであり、 $\mathrm{m}^{1}, \mathrm{~m}^{2}$ 共に有意差が存在 する(第 2,3 表)。

* 本研笙は文部省雨學研究費による。 
Table 2. Measurements of the crown ( $\delta$, in $\mathrm{mm}$.).

\begin{tabular}{|c|c|c|c|c|c|c|c|c|c|c|}
\hline & \multicolumn{3}{|c|}{ Mesio-distal diameter } & \multicolumn{3}{|c|}{ Bucco-lingual diameter } & \multicolumn{3}{|c|}{ Length-breadth index } \\
\hline & & $\mathrm{J}$ & $\mathrm{W}$ & $\mathrm{N}$ & $\mathrm{J}$ & W & $N$ & $\mathrm{~J}$ & W & $\mathrm{N}$ \\
\hline \multirow{5}{*}{$\mathrm{m}^{1}$} & $n$ & 44 & 46 & 16 & 52 & 48 & 16 & 45 & 46 & 16 \\
\hline & $\bar{x}$ & 7.2 & 7.2 & 7.6 & 8.9 & 8.7 & 9.1 & 122.8 & 120.9 & 118.7 \\
\hline & $\sigma$ & 0.39 & 0.37 & 0.46 & 0.42 & 0.55 & 0.47 & 6.5 & 7.2 & 5.6 \\
\hline & $\mathrm{S}_{x}$ & 6.60 & 6.08 & 3.36 & 9.36 & 14.40 & 3.52 & 1885.5 & 2369.0 & 500.8 \\
\hline & $\mathfrak{U}^{2}$ & 0.15 & 0.15 & 0.22 & 0.18 & 0.31 & 0.23 & 42.9 & 52.6 & 33.4 \\
\hline \multirow{5}{*}{$\mathrm{m}^{2}$} & $n$ & 46 & 45 & 15 & 52 & 49 & 17 & 45 & 45 & 15 \\
\hline & $\bar{x}$ & 9.3 & 9.1 & 9.5 & 10.1 & 10.0 & 10.1 & 108.6 & 109.9 & 107.2 \\
\hline & $\sigma$ & 0.52 & 0.49 & 0.44 & 0.46 & 0.51 & 0.42 & 4.2 & 5.2 & 5.6 \\
\hline & $\mathrm{S}_{x}$ & 12.42 & 10.80 & 2.85 & 10.92 & 12.74 & 3.06 & 778.5 & 1210.5 & 465.0 \\
\hline & $u^{2}$ & 0.28 & 0.25 & 0.20 & 0.21 & 0.27 & 0.19 & 17.7 & 27.5 & 33.2 \\
\hline
\end{tabular}

Table 3. Measurements of the crown ( $\%$, in $\mathrm{mm}$. ).

\begin{tabular}{|c|c|c|c|c|c|c|c|c|c|c|}
\hline & & \multicolumn{3}{|c|}{ Mesio-distal diameter } & \multicolumn{3}{|c|}{ Bucco-lingual diameter } & \multicolumn{3}{|c|}{ Length-breadth index } \\
\hline & & $\mathrm{J}$ & W & $\mathrm{N}$ & $\mathrm{J}$ & W & $\mathrm{N}$ & $\mathrm{J}$ & $\mathrm{W}$ & $\mathrm{N}$ \\
\hline \multirow{5}{*}{$\mathrm{m}^{1}$} & $n$ & 52 & 22 & 20 & 57 & 22 & 20 & 52 & 22 & 19 \\
\hline & $\bar{x}$ & 7.2 & 7.2 & 7.2 & 8.8 & 8.4 & 8.6 & 122.7 & 119.9 & 120.8 \\
\hline & $\sigma$ & 0.40 & 0.35 & 0.61 & 0.42 & 0.33 & 0.51 & 6.1 & 4.5 & 9.6 \\
\hline & $\mathrm{S}_{x}$ & 8.11 & 2.64 & 7.40 & 10.26 & 2.42 & 5.20 & 1908.4 & 444.4 & 1765.1 \\
\hline & $u^{2}$ & 0.16 & 0.13 & 0.39 & 0.18 & 0.12 & 0.27 & 37.4 & 21.2 & 98.1 \\
\hline \multirow{5}{*}{$\mathrm{m}^{2}$} & $n$ & 53 & 21 & 16 & 61 & 22 & 19 & 53 & 21 & 17 \\
\hline & $\bar{x}$ & 9.3 & 9.0 & 9.0 & 10.0 & , 9.6 & 9.6 & 107.6 & 107.1 & 106.4 \\
\hline & $\sigma$ & 0.42 & 0.61 & 0.49 & 0.46 & 0.59 & 0.73 & 4.8 & 5.0 & 5.7 \\
\hline & $\mathrm{S}_{x}$ & 9.54 & 7.77 & 3.84 & 12.81 & 7.70 & 10.07 & 1203.1 & 518.7 & 552.5 \\
\hline & $u^{2}$ & 0.18 & 0.39 & 0.26 & 0.21 & 0.37 & 0.56 & 23.1 & 25.9 & 34.5 \\
\hline
\end{tabular}

Table 4. Statistical test of the crown measurements (o).

\begin{tabular}{|c||c|c|c|c|}
\hline Measurement & Tooth & $\mathrm{J}: \mathrm{W}$ & $\mathrm{J}: \mathrm{N}$ & $\mathrm{W}: \mathrm{N}$ \\
\hline \multirow{2}{*}{ Mesio-distal diameter } & $\mathrm{m}^{1}$ & $\mathrm{~J}=\mathrm{W}$ & $\mathrm{J} \ll \mathrm{N}$ & $\mathrm{W} \ll \mathrm{N}$ \\
& $\mathrm{m}^{2}$ & $\mathrm{~J} \doteqdot \mathrm{W}$ & $\mathrm{J} \doteqdot \mathrm{N}$ & $\mathrm{W} \ll \mathrm{N}$ \\
\hline \multirow{2}{*}{ Bucco-lingual diameter } & $\mathrm{m}^{1}$ & $\mathrm{~J}>\mathrm{W}$ & $\mathrm{J} \doteqdot \mathrm{N}$ & $\mathrm{W}<\mathrm{N}$ \\
& $\mathrm{m}^{2}$ & $\mathrm{~J} \doteqdot \mathrm{W}$ & $\mathrm{J}=\mathrm{N}$ & $\mathrm{W} \doteqdot \mathrm{N}$ \\
\hline
\end{tabular}

A sign of inequality shows significant differences.

$<: \alpha=0.05, \ll: \alpha=0.01$

3 群を比較すれば $\mathrm{m}^{1}$ に拈いて $\mathrm{J}$ と $\mathrm{W}, \mathrm{W}$ と $\mathrm{N}$ の間に有意差が認められるが J と $\mathrm{N}$ の間及び $\mathrm{m}^{2}$ に抢ける各群の間には差があるとはいえない(第 4 表)。一般に群間の差は近遠 心徑に比して少ないようである。新井（日本人、'37), B LACK（白人、'02）兩氏の成績を比 較しても頓舌徑の差は近遠心徑の差よりもはるかに少ない。 
Mt. Carmel の $\mathrm{m}^{2}$ では 10.6.10.7 mm とい5值が報告されているが、近遠心巠の場 合と同樣に現代人ではこれに比してかなり小さくなつている。これはすでに乳切葍。乳犬齒 及び下顎乳臼齿に和いても明らかな事賽である。

3. 齒冠長幅示數。上顎乳臼苳は近遠心徑よりも煩舌徑の方が大きく、從つて本示數は いずれも 100 を越える。性差も 3 群間の差もほとんど認められないが、 $\mathrm{m}^{1}$ において $\mathrm{J}$ と との間には明らかに有意差が存在する（第 2,3 表）。一般に $\mathrm{m}^{1}$ の值は $\mathrm{m}^{2}$ に比して 12 單位 ほど大きく、前者の方が頓舌方向に細長いといえる。この關係は下顎乳臼齒にもみられたこ とであるが、下顎では近遠心方向に細長いことが上顎と異る。齒冠長軸の方向が他の齒と哄 ることは乳齿のみならず上顎大臼药にもみられることである。

觀 察

下顎乳臼齒の場合と同樣に本篇でも咬頭の名稱は OsBoRn の命名に從う。郎ち、protocone=近心舌側咬頭 (略號 $\mathrm{Pr}$ ), paracone=近心煩㑡咬頭 $(\mathrm{Pa})$, metacone=遠心煩側咬 頭 $(\mathrm{Me})$, hypocone=遠心舌側咬頭 $(\mathrm{Hy})$.

A. 上顎第 2 乳臼齒。

1. 齒冠の一般的形態。 $\mathrm{m}^{2}$ の齒冠は protocone, paracone, metacone 及び hypocone の 4 咬頭よりなり、各咬頭には原則として中心隆線とその兩側を走る 2 本の弱い副隆

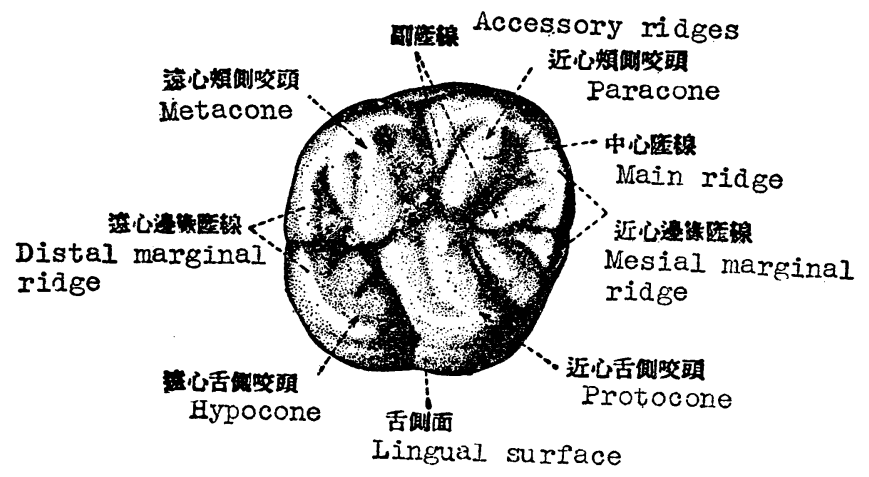

Fig. 1. Occlusal view of the upper molar (semi-schematic, after FUJITA, '49).

線とが存在する。これらの 咬頭は溝によつて境されて 扣り、その溝は全體として H型に近い(第 1 圖)。この ような形態は $\mathrm{m}_{2}$ が $\mathrm{M}_{1}$ に 似ていたように $\mathrm{M}^{1}$ に極め てよく似ているが、細かい 特徴については多くの差琪 を見出すことができる。

2. 齒冠の pattern. $\mathrm{m}^{2}$ 及び上顎大臼鋾には下 顎齒ほど複雜な分化はみら れないが、その pattern にはやはり種々の變化が起つている。その中で最も眼につき易い のは hypocone の大きさの變化であり、大臼齒の場合には $\mathrm{M}^{1}, \mathrm{M}^{2}, \mathrm{M}^{3}$ の順に退化の程度 が强くなる。DAHLBERG（'49）はこの退 化程度によつて齒冠の pattern を4段 階に區別した。郎ち “4”は 4 咬頭共よ く發達しているもの、“4一”は hypocone がやや退化しているもの、“3+” は hypocone の退化が强く、3咬頭性 の齒冠の遠心部に小結節の附着している 程度のもの、“3”
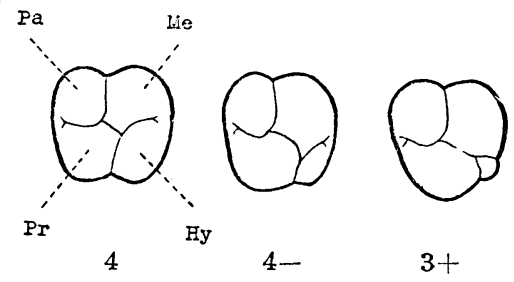

$3+$

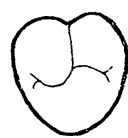

3

Fig. 2. Four types of upper molar crown (after DAHLBERG, '49). 
退化して完全な 3 咬頭性になつているものである(第 2 圖)。

この方法に從つて $\mathrm{M}^{1}$ を分類した成績では“4”の頻度は American White children (DAHLbERG) の 69\%を最低として Northwest Eskimo（同上）88\%、Pima Indian (同上) 99.4\%、East Greenland Eskimo (PEdersen, '49) 100\%となつている。こ の值は $\mathrm{M}^{2}$ に至つて急に低くなり、 $\mathrm{M}^{3}$ になると $37 \%$ を越えるものがない。このような hypocone の退化は下顎大曰齒に抢ける咬頭減少の傾向と一致するものであり、いわゆる Dryopithecus pattern の退化して行く各段階の頻度の變化が上顎大臼齒の pattern のそ れとほぼ本行した數值をとつているのは興味深いことである。

さて $\mathrm{m}^{2}$ では“3+”及び “ 3 ” は全くみられずすべて 4 咬頭であるが、 hypocone が 小さく“4一”の段階にあるものは稀ではない。私は“4”と“4一”とを區別する基準と

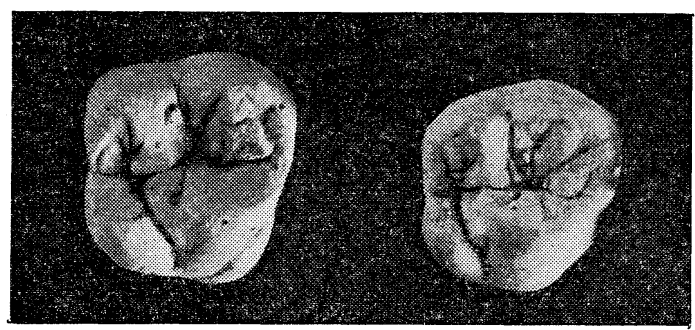

a

$\mathrm{b}$

Fig. 3. Two types of $\mathrm{m}^{2}$. a, " 4 " type (BM 47-19); b, “4-” type (BM 48-2).

して第 3 圖に示す標本々選び、これと對 照しながら分類した。その結果は第 5 表 の通りである。

日本人の上顎大田齒に關する研究は未 だ行われていないようであるが、私（埴 原、’54 a）の調查した混合齒列の場合に は $\mathrm{M}^{1}$ の “4”の頻度は $85.7 \%$ となつて おり、 $\mathrm{m}^{2}$ と汷とんど戀らない。

一方 Wの $\mathrm{m}^{2}$ では“4”が減少し、 Am. White children の $\mathrm{M}^{1}$ の頻度に

Table 5. Frequencies of the crown patterns in $\mathrm{m}^{2}(\%)$.

\begin{tabular}{|c|r||r|c|c|c|}
\hline Group & $\mathrm{n}$ & 4 & $4-$ & $3+$ & 3 \\
\hline $\mathrm{J}$ & 110 & 84.5 & 15.5 & - & - \\
$\mathrm{W}$ & 70 & 75.7 & 24.3 & - & - \\
$\mathrm{N}$ & 36 & 83.3 & 16.7 & - & - \\
\hline
\end{tabular}

かなり接近している。 $\mathrm{N}$ は J と大差がない。從つて 3 群中では W で最も hypocone の 分化が弱いといえるであろう。

3. CARABELlI 結節。本結節は進化の過程に扣いて比較的新しく獲得された形質であ るといわれている。郎ち Australopithecinae や Neanderthal では單なる pitとして のみ存在し、又 Sinanthropus の上顎大兒齒 23 本中には全くみられないという。一方現代 人に蚝比較的多く現われて和り、特に白人に多い。WHEELER（'50）はこのためか、本結節 を全く正常なものとみなし、第 5 咬頭（5th cusp）と呼んでいる。DAHLBERGによればこ の結節はアジア諸人種及び Eskimo には非常に少なく、彼等が白人と混血すれば多くなる そいう。しかしこの頻度を訬算する際にはどの程度のもの迄含めるかという基準のとり方に よつて數值が大きく左右されると考えられるので、多くの觀察者の結果をそのまま比較する ことは危險である。琴在の所では同じ著者の成續のみを比較してこの伦險を取除く以外に方 法はないが、DAhlberG, Pedersen 等は白人、Eskimo, American Indian を各々調査 しており、その成績の示す限りでは上記の結果を認めてもよいと思われる。 
日本人の大臼齒についても多くの報告があり、その結果も一致していないが、馬 ('49) に よれば $\mathrm{M}^{1}, r t$.における頻度は $12.8 \%$ となつている。

DIETZ（'44）は本結節の程度を ridged, pitted, lobular, cuspoid の 4 段階に分類した が、實際問題としてはその基準を一定することが困難である。

私は $\mathrm{m}^{2}$ における頻度を調べるに當つてやはり DIETZ の如く分類するのが適當ではない かと洘えたが、不正確になることを恐れて trace, pit 及び distinct の 3 段階に大別した。 trace は DiETz の ridged に、distinct は lobular 及び cuspoidにほぼ一致するもの と思われる。

Table 6. Frequencies of the CARAbelli's cusp in $\mathrm{m}^{2}(\%)$.

\begin{tabular}{|c|r||c|c|c|c|}
\hline Group & $\mathrm{n}$ & Trace & Pitted & Distinct & Total \\
\hline $\mathrm{J}$ & 113 & 15.0 & 24.8 & 8.8 & 48.7 \\
$\mathrm{~W}$ & 70 & 12.9 & 45.7 & 15.7 & 74.3 \\
$\mathrm{~N}$ & 37 & 10.8 & 54.1 & 5.4 & 70.3 \\
\hline
\end{tabular}

第6 表によれば trace まで入れると $\mathrm{m}^{2}$ に拈ける頻度は著しく高い。中でも最も多いの はいわゆる pitであつて、本結節の存在するものの牛數以上をこの形態が占めている。この 事賽は JONES（'47）もすでに指摘した所である。しかし pitを果して CARABELLI 結節の

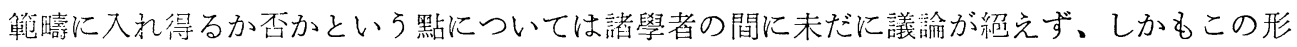
態が統計上大きい數を占めていることは本結節の砾究にとつて重大な問題である。從つて今

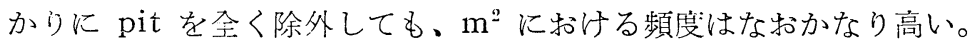

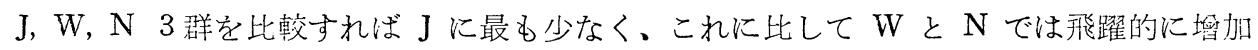
している。これは大四蕠において白人に多く、Mongoloid に少ないことと對應しているも のと思われるが、Negro に關する資料がないので N については何もいえない。

本絬箼の成因については cingulum の遗殘であるとする說が有力であり、これが比較的 新しい形質であるという理由で直ちに進化的な特徵であるとはいえないように思われる。何 となれば cingulum の遗殘と考学られるものはこのほかにも切齒及び犬基基底結節、下 顎大臼莮の protostylid 等があり、これらは一應原始的形態と考兄られるからである。從 つて CARABELLI 結節の頻度がこれらの他の形質と本行しないという事實の解釋は今後の磔 究にまたなければならないと考壳られる。

なお CARABELLI 結節が極めてよく發達し、咬頭狀を呈するものが J に 3 例 (2.7\%)、W

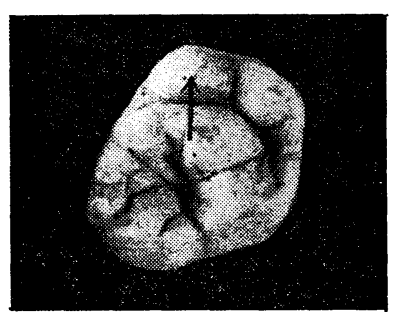

Fig. 4. Strongly developed CARABEIII'S cusp $(\uparrow$, WF $48-$ 11). に 2 例 (2.9\%)、N に 1 例 $(2.7 \%)$ 認められた。その最も强い ものではこの結節が hypocone と同大かむしろやや大きく、 protocone は煩遠心側に壓迎され、その大きさも蔆縮してい る。又 CARABELLI 結節と hypocone とは舌側面に拈ける淺 溝によつて境されているのみで連續しているが、paracone と metacone は余り影響を受けていないようにみえる(第 4 圖)。 この蒛の近遠心徑、煩舌徑は拈の打の $8.9,9.5 \mathrm{~mm}$ で共に本均 值に近いが、これは代償的に protocone が菱縮し、又その位 狊を變えているためと思われる。DAHLBERG によればこのよ 
ろな例は白人及び Melanesian の大臼苳にも稀にみられるという。

4. Protoconule. Protoconule は protocone と paracone とを結ぶ隆線（近心 邊緣隆線）が前者から發して近心に向い,ついで煩側へ折れる角の位置に生ずる小絬節であ る。

これは化石靈長類の多くのものによく發達し、lower Eocene の Lemuroid である Pelycodus ralstoni (MATTHEw, '15) を始め. Miocene の Proconsul (LE Gros ClaRK \& Leakey, '51), Dryopithecus (Gregory \& Hellman, '26) 等にみられる。

GrEGORY \& HELLMAN ('26) は本結節が一般に原始的な靈長類の特徽であることを記載

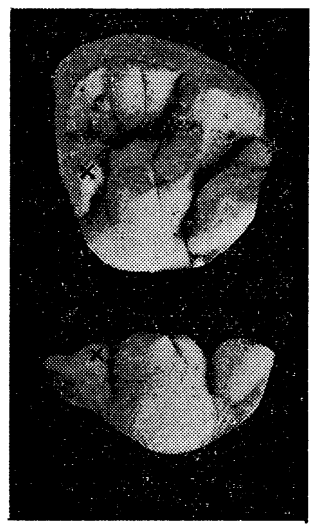

Fig. 5. Protoconule in $\mathrm{m}^{2}(\times$, WM $50-$ 1). Upper, occlusal view ; lower, lingual view. したが、現代人の $\mathrm{m}^{2}$ にも多くの個體に和いて大なり小なり認める ことができる(第 5 圖)。私の觀察した範圍ではJで 107 例中 95 例 (88.8\%) に認められた。

本結節の存在するものを舌側からみると protocone の近心側に 小咬頭が突出し、 protocone 及び hypocone と共に 3 個の山が でさているのが分る。よく發達したものではその高さが protocone に接近していることもある(第 5 圖)。又更にこのよ5な例では舌側 面に括いて protocone と protoconule を境する溝が發達して いるが、これはいわゆる CARABELLI's pit と丁度同じ位置に存在 する。從つてこの兩者は何等かの關係をもつているのではないかと 考えられるが、この點については更に後日の研究にまたなければな らない(第 5 圖下參照)。

$\mathrm{W}$ 及び N における protoconule の頻度はそれぞれ 86.8\%(68

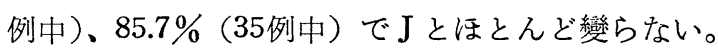

5. Metaconule. Protoconule と同樣の小結節であるが、その位置は斜走隆線 (crista obliqua) 上の metacone に寄つた點にある。やはり Pelycodus, Dryopithecus 等に みられるが、Sinanthropus (WEINENREICH, '37) にも明瞭に認めることができる。

本結節の存在する時には斜走隆線が階段状を呈することもあり、弱い時には隆線が途中で くびれているょうにみえることもある。從つてこれは私が $\mathrm{m}_{2}$ に拈いて distal trigonid crest の痕跡ではないかと記載した發育良好な metaconid の中心隆線、或いは清水（'55） が下顎大臼齒に和いて中心不全結節として記載したものとよく 似ている (第6 圖)。GREGORY \& Hellmax ('26) は本結節も protoconule と同じく原始的靈長類の特徵であると考えた。

私が今回觀察した範園では、この結節は多くの場合 protoconule より明膫であるが、その頻度はJに执いて77.8\%(108 例中）で protoconule より低い。この差は統計學的に有意で ある。一方 W では 70.6\% (68 例中)、N では 72.2\% (36 例 中）となつて扣り、同一群中の protoconule の頻度と比較し ていずれも有意差をもつて小さいが、各群の間の有意な差は認

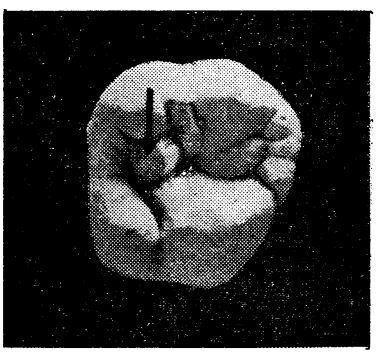

Fig. 6. Metaconule in $\mathrm{m}^{2}(\downarrow, \mathrm{NM} 50-3)$. められない。

6. 近心結節及び crista transversa. $\mathrm{m}^{2}$ の大部分のものに拈いて近心溝 (central 
groove of central fossa, WHEELER, ’50) の近心端の位置に小結節が存在する。私はこ れをかりに“近心結節”と呼びたい（第 7 圖 a)。

この結節は通常齒冠の近遠心軸上に位置し、近心窩を埋めていることが多いが、時にはわ ずかに煩側に寄つて paracone に附屬しているようにみえることもある。この場合には paracone の近心副隆線が特に發達したもののようにみえることが多いが、副隆線が別に存

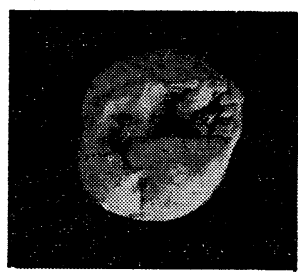

a

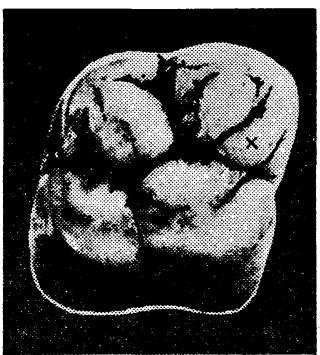

b

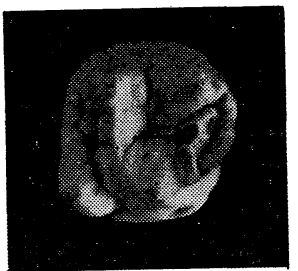

c

Fig. 7. Mesial tubercle (近心結節) and crista transversa. a, Mesial tubercle ( $x$, WM 48-5); b, Mesial tubercle or 5 th cusp in Gigantopithecus ( $\times, \mathrm{M}^{2}$, after KoENIGSWALD); c, crista transversa $(\rightarrow, \mathrm{NM} 50-1)$.

在することもあるのでやはり獨立した結節と考えるのが妥當ではないかと思われる。

KoenIGswald ('52) は Gigantopithecus の $\mathrm{M}^{2}$ には2 次的な“5th cusp”があり（第 7 圖 b)、その位置が orang において近心简の遠心壁を構成する酦襞に一致することを指 摘した。この 5 th cusp は形態、位置ともに上述の近心結節に全く一致しており、兩者は 同じ性質のものであると考元ても差支光ないように思われる。これは又 WEIDENREICH ('45) が Gigantopithecus に打いて “flower-bud pattern”と名づけ、paracone の派生物で あると記載したものである。更に KoENIGSWALD によれば現代 Java 人の上顎大臼齒にも 同樣の結節を認めうるという。

Gorilla の上顎大臼苜には近心邊緣隆線の遠心側にも51本の隆線が煩舌方向に走り、前 者は近心窝の近心壁を、後者は遠心壁を形成する。この隆線を crista transversa というが。 このうち遠心側の隆線は gorilla のみならず他の現棲類人猿や Australopithecus にも存 在する。しかし Dryopithecus, Sinonthropus, Krapina, Le Moustier 等では弱い (WEIDENREICH, '37)。現代人では大臼齒、乳鼠齒に全くみられないとされているが、私は 比較的よく發達しているものを 1 例認め得た（第 7 圖 $\mathrm{c}$ )。

この例では近心結節が極めてょく發達しているのみならず、 protocone の近心副隆線も 强く、兩者が合して 1 本の橫走する隆線を形成している。これは gorilla に拈ける cristo transversa の形態と極めてよく似ており、このような例からみれば近心結節とこの隆線 とは深い關係をるつているのではないかと想像される。郎ち近心結節は crista transversa の遺殘ではないかと考えられるのであるが、この點に關しては今後の研究が必要であろ 万。

な怙 KoENIGSWALD は近心絬節 (5th cusp) が protoconule と同一物であると記載して いるが、前者は主として近心窩ないし paracone に寄つた位置にあり、後者は protocone の近心側に存在することを考えれば兩者は全く異るものと思われる。 
$\mathrm{m}^{2}$ に打ける近心結節の頻度は J 77.9\% (109 例中)、W 77.5\% (71 例中)、N 82.1\% (39 例中）で各群ともほとんど變らない。

7. 斜走隆線 (crista obliqua). この隆線はいうまでもなく metacone の中心隆線 と protocone の遠心副隆線とが 1 本の比較的明瞭な隆線となつて連結したものである。そ の發達程度は樣々であるが、一般に Proconsul, Limnopithecus, Dryopithecus 等の化石靈 長類及び gorilla, chimpanzee では極めてよく發達している。しかし WEIDENREICH ('37，'45）によれば、Sinanthropus には少なくとも猿類に抢ける如き意味での crista obliqua は存在しないという。同樣のことは Krapina, Le Moustier にも認められ、更 に Gigontopithecus にも明瞭な隆線は存在しない。

現代人の上顎大臼齒では一般に弱く鈍い隆線として認められるのみであり、全く存在しな いものも稀ではない。VRAM (1897) によれば現代ヨーロッパ人の $\mathrm{M}^{1}$ において本隆線の存 在するものは $49.8 \%$ に過ぎないというが、その發達の程度をどのような基準によつて分ける かという問題は困難である。しかし少なくとも現代人には猿類の如き强く銳い隆線はないと 考えても差交えないようである。

$\mathrm{m}^{2}$ に拈いても本隆線の强いものは少なく、 paracone の中心隆線に比してやや明膫であ る程度のものが多い。しかし中には極めて銳く、强く發達しているものもある。 $\mathrm{m}^{2}$ と大臼

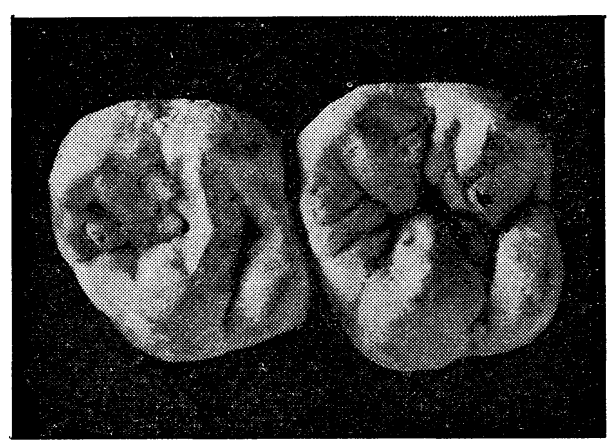

$\mathrm{m}^{2}$

Fig. 8. Crista obli ua in a mixed dentition (BF 47-14).

齒とを比較した資料はないが、私の手元にある 混合齒列の標本 36 例ではすべて $\mathrm{m}^{2} よ り \mathrm{M}^{1}$ の方が斜走隆線の發達は弱い(第 8 圖)。この理 由は後者に扮いて隆線そのものの發達が弱いと いうこともあるが、著しいのは本隆線を越えて 遠心に走る中心溝 (transverse groove of oblique ridge, WHEELER)が $\mathrm{M}^{1}$ でよく發達 し、そのために斜走隆線が銳く切斷されている ことにもよる。これに對して $\mathrm{m}^{2}$ では中心溝が なく、隆線がその全長にわたつて完全に連續し ていることが多い。しかしこの問題についても

將來更に檢討する必要があると考光られる。

AbEL ('31) は Austrolopithecus に打いて、斜走隆線の舌溉端が protocone の尖頭では なく、この遠心㑡にできている副咬頭に終つていることを記載 した。WEIDENREICH ('37) は同樣の形質が Sinanthropus に もみられることを指摘したが、私も $\mathrm{m}$ ゙においてこのような例 を認めた (第 9 圖)。この例では斜走隆線は弱いが中心溝によつ て切斷されることなく metacone から protocone に向つて 連續している。又問題の protocone の遠心に存在する副咬頭 はよく發達し、右側畧では protoconule よりもはるかに明瞭 である。これに對して左側齒ではやや弱い。舌側面には protocone の尖頭とこの副咬頭との間に明膫な溝が存在し、そのた め protoconule の存在と相俟つて protocone が 3 分され

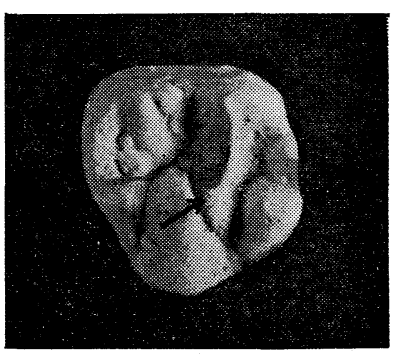

Fig. 9. Crista obliqua and distal accessory cusp $(\rightarrow$, WM 50-1). 
ているようにみえる。しかしこの副咬頭がいかなる形態學的意味をもつているか今の所明ら かでない。

斜走隆線に關して J, W, N 3 群の間に差はないようである。

8. 賽側面の浮彫像。 $\mathrm{m}^{2}$ の頓側面には時としてかなり明瞭な浮彫像のみられることが ある。多くの場合これは paracone の部分に限つて現われるが、稀には metacone にま で及ぶことがある。その形態は下顎齒の protostylid に極めてよく似て抢り、齒頸部より 發して細くなりながら paracone の尖頭に向う。その先端は尖頭に達することもあるが途

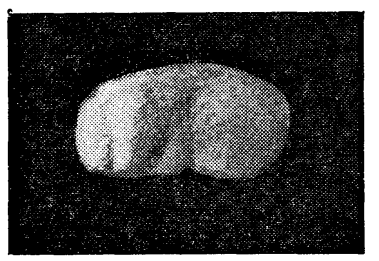

Fig. 10. Relief on buccal surface ( $\mathrm{m}^{2}$, FF $\left.46-1\right)$.

中で消失するものが多い（第 10 圖）。

WeIDENREICH ('37) は Sinanthropus の $\mathrm{M}^{1}$ 及び $\mathrm{M}^{2}$ の大 部分の例でこのような浮彫像がみられるとし、これを“moonshaped ridge”と呼んだ。同氏はこれが cingulum に由來 するものであると記載したが、もしそらならばこれは protostylid や CARABELLI 結節と同じ起源をもつものであると栲 壳られ。

現代人上顎大臼齒でこの形質を調查した文献を私は知らないが、WEIDENREICH は現代人 には全く起らないものであるといつている。しかし上述の如く $\mathrm{m}^{2}$ にはさほど稀ではない。 その頻度は J 18.8\% (112 例中)、W 15.5\% (71例中)、N 15.8\% (38 例中) であつて各群 とも差は汪とえどないが、これらの數值は下顎齒の protostylid に比してかなり低く、N

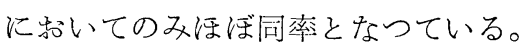

この結節の發達に關しては、單に弱い膨隆ないし躈譬として認められる程度のものが大部 分を占め、第 10 圖の如き比較的明膫なものは總個體數 221 例中わずかに 3 例 $(1.4 \%)$ の であつた。從つて本形質は $\mathrm{M}^{1}$ にはたとえあつても菎だ稀であることが推測されるが、今後 この點とともに protostylidやCARABELLI 結節等との關係を研究する必要があると考え られる。

B. 上顎第 1 乳臼苳。

1. 齒冠の一般的形態。 $\mathrm{m}^{1}$ の齒冠形態はその代生齒である $\mathrm{P}^{1}$ とも後續齒である $\mathrm{m}^{2}$ とも著しく異つているが、乳臼齔中ではその代生齔に最もよく似ているといわれている（藤 田、'49)。一般に protocone 及び paracone はよく發達しているが metacone 及び hypocone は極めて弱いか又は全く分化していない。

2. Metacone 及び hypocone の分化。 $\mathrm{m}^{1}$ の咬頭の數に關しては研究者によつて種 々の見解がとられている。郎ち藤田は 2 咬頭性であるとし、BLACK ('02), JONES ('47) 等 は3 咬頭性、W WEELER（'50）は 4 咬頭性であると述べている。このような韲亂が起るのは metacone 及び hypocone の分化が不完全なためであつて、どの形態が最も一般的なも のであるかを決定するのは困難なことである。しかし詳細に觀察すればこれら兩咬頭が痕跡 的にではあるが分化しているものが多く、4咬頭性の形態に近づこうとする傾向が明らかに 認められる (第 11 圖)。これは $\mathrm{m}_{1}$ にも認められた現象であり、この點で $\mathrm{m}^{1}$ 及び $\mathrm{m}_{1}$ の間 に本行關係が存在すると考兄られようである。

Metacone と hypocone との分化の程度を比較すると一般に前者の方が强く、大部分 の個體に大なり小なり現われている。しかしその咬頭の高さは隣接する paracone には及 
ばず、鈍い隆起として認められることが多い。時には煩側面において paracone との間に 淺い分界溝の存在することもある。

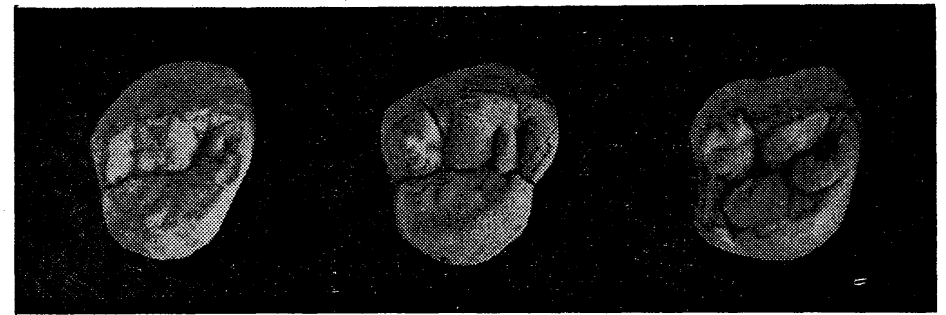

a b c

Fig. 11. Three types of $\mathrm{m}^{\mathrm{x}}$.

a, 2 cusped (WM 49-1); b, 3 cusped (NM 50-3);

c, 4 cusped (BM 47-21).

cone に對する大ささは $\mathrm{m}^{2}$ の hypocone に遠く及ばない。

Table 7. Frequencies of the metacone and hypocone in $\mathrm{m}^{1}(\%)$.

\begin{tabular}{|c|c|c||r|r|}
\hline Group & Cusp & $\mathrm{n}$ & None & Distinct \\
\hline \multirow{2}{*}{$\mathrm{J}$} & $\mathrm{Me}$ & 106 & 7.5 & 27.4 \\
& $\mathrm{Hy}$ & 104 & 31.7 & 22.1 \\
\hline $\mathrm{W}$ & $\mathrm{Me}$ & 71 & 1.4 & 22.6 \\
& $\mathrm{Hy}$ & 70 & 32.8 & 8.6 \\
\hline $\mathrm{N}$ & $\mathrm{Me}$ & 35 & 5.7 & 37.2 \\
& $\mathrm{Hy}$ & 35 & 20.0 & 25.7 \\
\hline
\end{tabular}

第 7 表は $\mathrm{m}^{1}$ に打ける metacone 及び hypocone の存在しないもの、並びに明瞭なもの の頻度であるが、本表に記入していない部分の個體はすべて痕跡的にこれらの咬頭が分化し ているものである。この表からみると多くの個體において分化が認められ、特に metacone の全く存在しないものは極めて少ない。又表中明膫なもの (distinct) とは隣接咬頭との間 にわずかでも分界溝が存在し、その先端が小咬頭として分化しているものであるが、このよ うな形態は各群とも hypocone よりも metacone に多くみられる。上顎大四齒の進化に 执いて metacone の次に hypocone が形成されたとの說 (tri-tubercular theory)を考 えれば以上の現象は全く當然であると思われる。

本形質に關して各群の間に差はみられない。

3. CARABELLI 結節。 $\mathrm{m}^{2}$ と同樣に $\mathrm{m}^{1}$ にも本結節の存 在することがある。しかしその頻度は $\mathrm{m}^{2}$ に比して極めて低 く、發達の程度も弱い(第 12 圖)。多くは“ ridge” の程度 のもので、 $\mathrm{m}^{2}$ や大臼苳にしばしばみられるような舌狀の隆起 になつているものはない。又 pit も極めて少なく、W (71例) の中に 3 例 $(4.2 \%)$ 認められたに渦ぎない（第 8 表)。

$\mathrm{m}^{1}$ に CARABELLI 結節の存在する時には $\mathrm{m}^{2}$ にも常に存在 しており、後者の方が强い場合が多い。しかし逆に $\mathrm{m}^{2}$ に强い

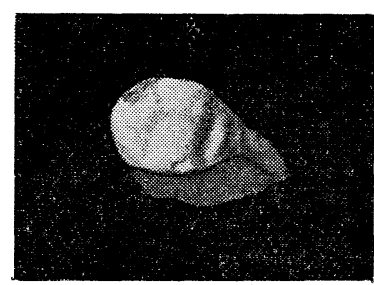

Fig. 12. CARABEIII'S cusp in $\mathrm{m}^{1}$ (WM $46-1)$. 
Table 8. Frequencies of the Carabelli's cusp in $\mathrm{m}^{1}(\%)$.

\begin{tabular}{|c|r||c|c|c|}
\hline Group & $\mathrm{n}$ & None & Trace & Pitted \\
\hline $\mathrm{J}$ & 113 & 89.2 & 10.8 & - \\
$\mathrm{W}$ & 71 & 71.8 & 24.0 & 4.2 \\
$\mathrm{~N}$ & 36 & 94.4 & 5.6 & - \\
\hline
\end{tabular}

結節がある時、必らずしも $\mathrm{m}^{1}$ にも存在するとはいえない。

$\mathrm{J}, \mathrm{W}, \mathrm{N} 3$ 群の中では $\mathrm{W}$ に最も多く、J, N の順に少なくなる。W に最も多いという傾 向は $\mathrm{m}^{2}$ でも認められた現象であり、 $\mathrm{J}$ と $\mathrm{W}, \mathrm{W}$ と $\mathrm{N}$ との間にはいずれも有意差が存在 する。

4. 斜走隆線。一般に $\mathrm{m}^{1}$ には斜走隆線が發達していないが metacone 及び hy pocone の比較的よく分化している場合には本隆線の認められることが多い。その强さはもちろん $\mathrm{m}^{2}$ に比較して低く、細く又鈍いが明瞭である（第 13 圖 a)。

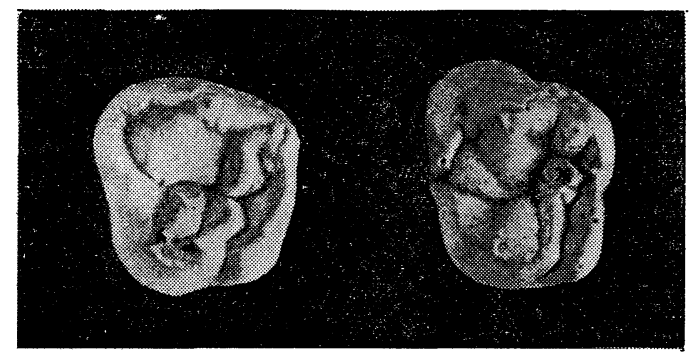

a

b

Fig. 13. Crista obliqua and metaconule in $\mathrm{m}^{1}$.

a, crista obliqua (NM 50-1);

b, metaconule $(x, \mathrm{BM} 47-21)$.

Jではこの隆線の存在するものが 23.8 \%（122 例中）に達しており、これに對 して W では $15.5 \%$ (71例中)、 $\mathrm{N}$ では 21.1\%（38 例中）とやや少なくなつてい る。

この隆線と metacone 及び hypocone を同時に觀祭すれば、 $\mathrm{m}^{1}$ が $\mathrm{m}^{2}$ や $\mathbf{M}^{1}$ の如き形態に分化しょうとする傾向 をもつているとの印象を强く受けるであ ろう。稀には metaconule の存在して いることもあり、このような例では $\mathrm{m}^{2}$ との類似が更に著しい（第 13 圖 b)。

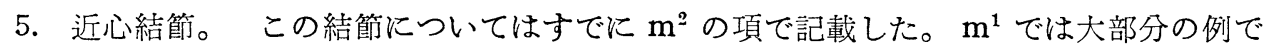
定形的に近心邊緣隆線と paracone の中心隆線との間に生じ、その形も頓舌方向に細長い ものが多い。又その位置は $\mathrm{m}^{2}$ では齒冠の近遠心軸上にあつたのに對して $\mathrm{m}^{1}$ では近心溝よ りも煩側に寄つている。從つてこの結節が paracone に附屬するものではないかとの印象は $\mathrm{m}^{2}$ の場合以上に强く、KoENIGSWALD の 如くこれが protoconule であるとは考 えられない(第 14 圖 a)。

本結節がよく發達したものでは近心邊 緣隆線との間に淺い近心窩 (fossa $a n$ terior)が形成され、crista transversaを 暗示するがこの點は $\mathrm{m}^{2}$ にみられた現象 と一致する（第 14 圖 b)。

近心結節の頻度は J に扔いて $52.9 \%$ (104 例中)、W $55.2 \%$ (67 例中)、 $\mathrm{N}$ $54.3 \%$ (35 例中) で各群間の差はなく、

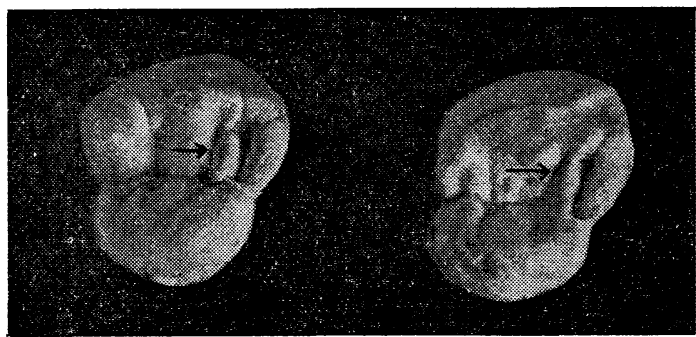

a

b

Fig. 14. Mesial tubercle (近心結節) and crista transversa in $\mathrm{m}^{1}$. a, mesial tubercle ( $\rightarrow$, NM 50-3); b, crista transiersa ( $\rightarrow$, FM 46-2). 
いずれも牛數をわずかに越える程度である。しかし $\mathrm{m}^{2}$ における頻度に比較するとこの值は はるかに低く、Jで檢定した結果 $\mathrm{m}^{1}$ 及び $\mathrm{m}^{2}$ の差は危險率 $1 \%$ 以下で有意である。

6. Cingulum. $\mathrm{m}_{1}$ では protoconid 煩側面の下部に tuberculum molare が存在 し、これが cingulum の一部であることを記載した。これと同じ形態が $\mathrm{m}^{1} に も$ 存在し、 paracone の煩側面の齒頸部に近い部分が膨隆している。これに体つて煩側の齒顠線は paracone の基部で急に上向し、そのために蓄钼線より計つた齒冠の高さ（重直徑）は遠心部

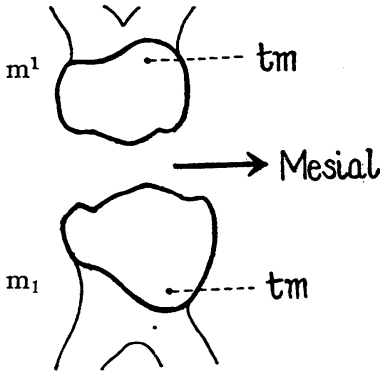

Fig. 15. Tuberculum molare ( $\mathrm{tm}$ ) in $\mathrm{m}^{1}$ and $\mathrm{m}_{1}$, buccal view. の值に比して近心部の方が著しく大きい。この形態は $\mathrm{m}_{1}$ でも同樣である (第 15 圖)。從つて $\mathrm{m}^{1}$ に打けるこの膨隆も tuberculum molore と呼んで差支えないであろうし、これ が cingulum の一部であることも $\mathrm{m}_{1}$ の場合と同樣に推测 し得るであろう。

更にこの部分から䓢冠の煩側面と近心面とを分ける偶解に 沿つて明瞭な隆線が起り、咬面に達していることがある。こ れもまた $\mathrm{m}_{1}$ に拉ける同樣の形態と對應しているものと考え られ、 $\mathrm{m}_{1}$ の場合に “ascending portion of the cingulum” (WEIDENREICH) と呼んだのに對して $\mathrm{m}^{1}$ のそれ “ “descending portion of the cingulum”と呼ぶ

とができよう（第16

圖 a)。

稀にはこの下行枝 が 2 分して片方が paracone の尖頭に 向つて伸びることが ある。これは缟 3 角形を呈し、その頂

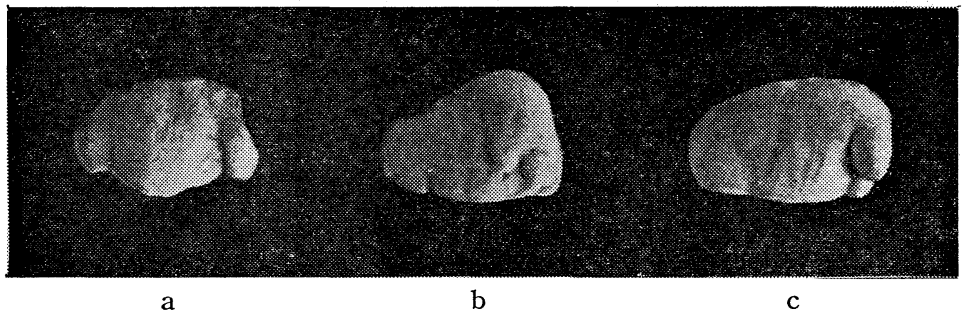

Fig. 16. Relief of buccal surface in $\mathrm{m}^{1}$. a, descending portion of the cingulum (WM 47-1); b, derivative of stylar cusp (BF 48-21); c, strongly developed relief (WF 51-11).

\section{ともあるが齒冠煩側}

面の途中で渻失することが多い。形態的にみればこれは下顎齒の protostylid に極めてょ く似ており、又前述の $\mathrm{m}^{2}$ 飞打ける煩側面の浮彫像と相同の形態であると考学られる（第16 圖 b)。同樣のものは Sinonthropus の上顎大臼齒にもみられ、WEIDENREICH によればこ れは stylar cusp の遺殘 (mesostyle) であるという。この特徵は Notharctus に最も著 明に認められる (GREGORY, '22)。

“Descending portion of the cingulum”の强い時には明暸な隆線を形成し、又咬 面の偶角部で小さいが明らかな結節を作る。このような場合に煩側からみると咬緣は paracone 及び metacone と共に下を向いた山字形をなし、更に强い時には 1 個の完全な結鎜 となつていることさえある(第 16 圖 c)。

$\mathrm{J}$ ではこの隆線が比較的よく發達し、周圍から明瞭に區別されらる程度のものは109例币 32例 (29.4\%) であり、この中の大部分は大なり小なり protostylid 樣の隆起を件つている。 しかし煩側面の偶角部が鈍い鼪璧をなしている程度の弱いものまで含めれば “descending 
portion” は洼とんどすべての個體に認められるといつてよい。W 及び N における比較的 明瞭なものの頻度はそれぞれ 71 例中 23 例 (32.4\%)、36 例中 11 例 (30.6\%) でJ と汪と んど變らない。

このような形態が cingulum ないしその遺殘であり、原始的な形質であると考えられる ならば、 $\mathrm{m}^{2} よ り も ~ \mathrm{~m}^{1}$ で多く又明瞭にみられるという事實は後者がより原始的特徵を保持 していることを物語るものといえよう。

考察

前章では各部分の形態について記載したが、本章では小曰蒛及び大曰齒との關連において $\mathrm{m}^{1}$ 及び $\mathrm{m}^{2}$ の占める形態學的位置に關する一般的考察を進めたい。以下の記述は第 III 篇 の下顎乳臼齒に關する考察と本行して行うので同論文も參照して頂きたい。

1. $\mathrm{m}^{1}, \mathrm{~m}^{2}$ 及び $\mathrm{M}^{1}$ の齒冠の形態學的關係。

一般に $\mathrm{m}^{1}$ の齿冠形態は $\mathrm{m}^{2}$ 及び $\mathrm{M}^{1}$ と著しく異つているといわれている。更に詳細に觀 察すれば比較的よく似ている $\mathrm{m}^{2}$ と $\mathrm{M}^{1}$ との間にも種々の點で相違は見出されるが、又逆に これら 3 齒を比較すれば共通した點も決して少なくない。ここでは主としてこのような共通 點について 2,3 の事項を記載することにする。

a. 咬頭の分化。 $\mathrm{m}^{1}$ は前章で述べた通り研究者によつて 2 咬頭性、3 咬頭性及び 4 咬頭 性と種々の見解が立てられている。この事實は $\mathrm{m}^{1}$ に扣ける咬頭分化が不安定であつて、こ れら 3 個の段階がいずれも實際に認められるからにほかならない。郎ち $\mathrm{m}^{1}$ では metacone 及び hypocone が發達の途上にあり、發達の極端に弱いものでは 2 咬頭性に.上此り、强い ものではすでに 4 咬頭性となつているものと解釋される。

一方 $\mathrm{m}^{2}$ では 4 咬頭がすべて完全に分化し、この點に關する限り $\mathrm{M}^{1}$ と同樣の段階に達し たものと思われる。しかし最後に分化したといわれている hypocone の大きさは、 $\mathrm{m}^{2}$ 及、

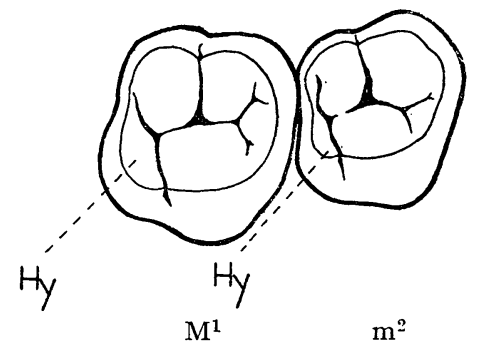

Fig. 17. Difference of comparative size of hypocone in $\mathrm{m}^{2}$ and $\mathrm{M}^{1}$ (traced from photograph).

び $\mathrm{M}^{1}$ の共存する混合齒列をみれば後者の方が相對的に 大きい(第 17 圖)。これを更に具體化するために私は “hypocone-index”なるものを計算した。これは齒 冠の近遠心聼を a とし、この徑に本行に、遠心画側溝 (distal oblique groove, WHEELER) が击側の切緣を 切る點から遠心面迄の投影距離をb とした時、 b × $100 / \mathrm{a}$ で與壳られるので、 hypoconeの齒冠に對 する相對的な大ささを 表わす示數である（第 18 圖)。 $\mathrm{m}^{2}$ 及び $\mathrm{M}^{1}$ の共存する日本人兒童の混合齒列 14 例 から計算した結果は第 9 表の通りである。郎ち本示數は明 らかに $\mathrm{m}^{2}$ の hypocone が $\mathrm{M}^{1}$ のそれよりも相對的に小 さいことを示し、兩者間には危險率 $1 \%$ で有意差が認めら れる。この事實は $\mathrm{m}^{2}$ の hypocone がまだ $\mathrm{M}^{1}$ における 汪ど强度に分化して抢らず、今な扮分化の途上にあること

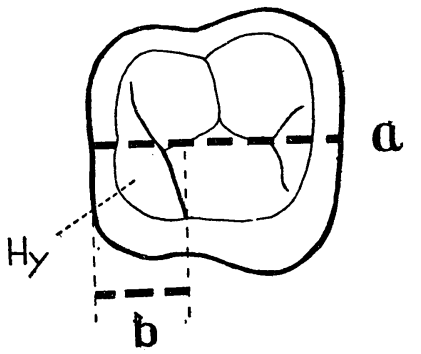

Fig. 18. Measurements for "hypocone-index". (Hypocone-index $=$ b $\times 100 /$ a.) 
Table 9. Hypocone-index in the mixed dentition of the Japanese children.

\begin{tabular}{|c|c||c|c|c|}
\hline Tooth & $\mathrm{n}$ & $\begin{array}{c}\text { Hypocone- } \\
\text { index(average) }\end{array}$ & $u^{2}$ & $\mathrm{~S}_{x}$ \\
\hline $\mathrm{m}^{2}$ & 14 & 30.1 & 9.91 & 128.80 \\
$\mathrm{M}^{1}$ & 14 & 34.1 & 10.18 & 132.30 \\
\hline
\end{tabular}

を物語るものと考えられる。

以上の諸點を考えれば、咬頭の分化に關しては $\mathrm{m}^{1} \rightarrow \mathrm{m}^{2} \rightarrow \mathrm{M}^{1}$ の順に段階的に進んでいる との推測が立てられるように思われる。

b. 斜走隆線。 $\mathrm{m}^{1}$ ではこの隆線はほとえど認められないが、 metacone 及び hy pocone の分化に体つて弱く現われていることもある。これに對して $\mathrm{m}^{2}$ では一般に明暸で銳い。 $\mathrm{M}^{1}$ では再び弱くなり、ほとんぞ認められないものも少なくない。この現象は上述の咬頭の分化 が一方向的に進んでいたのに對して異つた樣相を示しているが、 $\mathrm{m}^{1}$ と $\mathrm{M}^{1}$ とで同じように 隆線が弱いといつてもこれは相同の現象とは考えられない。郎ちこの場合、 $\mathrm{m}^{1}$ ではまだ隆 線の分化が進まないために少ないのであり、 $\mathrm{M}^{1}$ ではすでに退化し始めたために弱くなつた のではないかと考觉らるのである。

化石靈長類に眼を轉ずると、 $\mathrm{M}^{1}$ に拈ける hypocone は Proconsul, Dryopithecus を始 め Gigantopithecus, Sinanthropus, 更に下つて Neanderthal 等でも現代人よりはかな り大きい。しかるにその斜走隆線は Proconsul, Limnopithecus, Dryopithecus 等では明瞭 であるのに Gigantopithecus や Sinonthropus ではすでに退化している。この事實は、 hypocone と斜走隆線との進化の相が一致しておらず、後者の方が早くから退化し始めた ことを示すものであろう。もしそうならば、現代人においてもこれら兩形質がその分化の程 度を異にし、 $\mathrm{m}^{1} \rightarrow \mathrm{m}^{2} \rightarrow \mathrm{M}^{1}$ の系列において一方は直線的に分化が進みつつあり、他方はす でに退化が始まつていると考えても何等の矛盾も起らないのではないだろうか。從つて分化 と退化とい5 2 樣の過程を考慮に入れるならば、ここでも $\mathrm{m}^{1}$ から $\mathrm{m}^{2}$ を通つて $\mathrm{M}^{1}$ に至る 形態學的關係を認めても差支えないと思われる。郎ちこの場合、 $\mathrm{m}^{1}$ では斜走隆線の分化が 始まりつつあり、これは $\mathrm{m}^{2}$ で一應完成するが、 $\mathrm{M}^{1}$ に至ると今度は徐々に退化し始めて明 瞭なものは少なくなるという一つの過程が考学られるのである。

c. 原始的な大臼䔢と $\mathrm{m}^{1}$ との形態學的關係。COPE-OSBORN の 3 結節說によると靈長 類の上顎大臼齒は 3 結節齒の段階を經て進化して來たものであるという。

Eocene の Pelycodus trigonodus (Adapidae), Omomys (Tarsiidae) 等の上䫓大臼齒 には hypocone がなく 3 咬頭性であり、齒冠の輪廓は活ぼ 3 角形をなしている。やや下つ て Nothorctus, Pronicticebus 等になると始めて hypocone が現われ、齒冠は 4 角形とな り、更に咬頭が丸味を叔びて來る(GREGORY, '34)。又 3 咬頭性の $\mathbf{M}^{1}$ は現棲の Lemuroidea にもみられるといわれ (OsBORN, '07), このよ5な事實から GREGORY ('16) は人類の 4 咬頭 性の上顎大曰齒の形態は第 3 紀の Anthropoid を經由して Eocene の 3 咬頭性の形態ま でさかのぼり得るという。

このような立場から現代人の $\mathrm{m}^{1}$ を觀察すると、その形態は原始的な 3 咬頭性の大臼荗に 極めてよく似ており、この齒が猫特な形をしていることは原始的特徴をより多く保持してい 
るためにほかならないことが明らかである。

以上のように $\mathrm{m}^{1}, \mathrm{~m}^{2}$ 及び $\mathrm{M}^{1}$ を比較すると種々の點で類似性と同時に相違する所も明ら かとなる。類似性とは分化又は退化の程度こと異つてもこれら 3 個の齒は同一の形態學的基 礎の上に立つているという點であり、相違點とは各乃の形態が異つた進化段階にあり、一見 すると相互の關係が極めて薄いようにみえることである。しかしこれらの關係はあくまでも 形質の進化という點からみて段階的な變化であり、そこに本質的な差は存在しないとみるへ きであろう。

2. $\mathrm{m}^{1}$ と $\mathrm{P}^{1}$ との關係。

JONEs ('47) によれば $\mathrm{m}^{1}$ の形態は小臼齒の特殊化したものであるという。又 DAHLBERG ('49) は $\mathrm{m}_{1}$ と $\mathrm{P}_{1}$ との䕰冠形態の差は “compression factor”によるもので、 $\mathrm{P}_{1}$ の形 は $\mathrm{m}_{1}$ が近遠心的に壓縮されたことによつて生じたものであると記載したが、これは $\mathrm{m}^{1}$ と $\mathrm{P}^{1}$ との間にも同樣に考えられることである。一方、兩者は talon 及び咬頭の未分化、頪舌 徑が近遠心徑に比して長いこと等において互いによく似ている。このために $\mathrm{m}^{1}$ は上顎小 臼齒の齒冠に上顎大臼齒の齒根を取りつけたようだ”（藤田、'49）ということもできるので ある。

Anthropoid の $\mathrm{P}^{1}$ は更によく人類の $\mathrm{m}^{1}$ に吹ている。郎ち前章でも記載したよ5に $\mathrm{m}^{1}$ には tuberculum molore が發達しているためにその部分で齒頸線が急に上昇している。 この形態は Dryopithecus や現棲類人猿の $\mathrm{P}^{1}$ にも明瞭に認められ、更に Sinanthropus の $\mathrm{P}^{1}$ でも tuberculum molare が强く同樣の形態を示している。しかしこの特徽は Krapina になると汪とんど退化して單に痕跡として認められるに過ぎない(GoRJANOVIĆ-KRAMBERGER, '06)。

以上の如く $\mathrm{m}^{1}$ と $\mathrm{P}^{1}$ とは一見異つているようであるが、後者の原始的形態はかなりよく $\mathrm{m}^{1}$ に似て抒り、 $\mathrm{m}^{1}$ (modern type) $\rightarrow \mathrm{P}^{1}$ (primitive type) $\rightarrow \mathrm{P}^{1}$ (modern type) と並べ て比較すれば互いに高い形態學的な類似性を認めざるを得ない。この關係は下顎乳臼齒の場 合にも全く同樣に存在したものであり、細部に關する差はあつても一般的にみてすべて同じ 傾向をむつているといえるであろう。

私は本章に拈いて臼齒群中に打ける $\mathrm{m}^{1}$ 及び $\mathrm{m}^{2}$ の形態學的位置について若干の考察を行 つたが、その結果から次のことが考えられるであろう。郎ち小臼菱、乳臼齒及び大臼苳は各

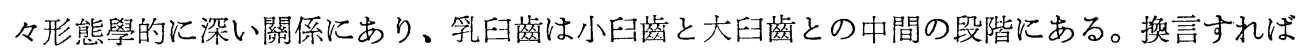

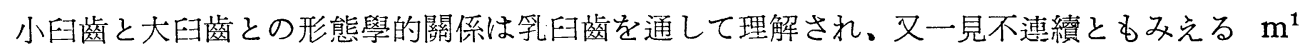
と $\mathrm{m}^{2}$ 並びに大臼齒との關係はそれぞれの原始的な形態を仲介とすることによつて明らかに されよう。

たびたび指摘したようにこれらの關係は根本的には下顎臼莮群の場合と全く同樣であり、 又この事實が藤田（'40）の大臼齒は第 1 齒列に屬するとい5考方方に少しも矛盾しないこと も變りがない。

結 論

本篇は上顎乳臼齒についての記載である。前 3 篇と同樣に本論中では主として乳齒齒冠の 正常形質に關する記載を行い、同時に日本人と日米混血兒とを比較した。主な點を要約すれ 
ば次の通りである。

1. 近遠心徑。 J及びWでは性差が認められないがNでは强い。3 群中ではNが最も大 きく、JとWの間には有意差がない(第 $2 \sim 4$ 表)。

2. 煩舌徑。W及びNに扔いて性差が明瞭である。3 群中ではWが最も小さい（第 2 〜 4 表)。

3 齿冠長幅示數。上顎乳臼茼では常に近遠心徑よりも煩舌徑の方が大きいために本示 數は 100 を越える。性差、群間の差は共にほとんどないが、 $\mathrm{m}^{1} に$ にいては $\mathrm{J}$ ととの間に 有意差が認みられ前者の方が大きい(第 $2 \sim 3$ 表)。

4. 咬頭の分化。 $\mathrm{m}^{2}$ は常に 4 咬頭性である。Hypocone のよく發達しているもの(“4” type）は全體の $3 / 4$ ないし $4 / 5$ を占め、この頻度は $\mathbf{M}^{1}$ と大㾤ないものと思われる。 3 群中で はWで比較的 “4” type が增加しているがJとNの間に差はほとんどない(第 5 表)。

$\mathrm{m}^{1}$ では metacone 及び hypocone の分化が極めて弱いが、比較的明瞭なものもある。 一般に前者の方が後者よりも分化の程度が强い。この形質に關しては 3 群間に大差がない (第 7 表)。

5. CARABELLI 結節。 $\mathrm{m}^{2}$ では痕跡的なるのまで入れると本結節の頻度は極めて高い。 又特に pit が多く、その頻度は全數の $1 / 2$ に達することがある。この現湬は $\mathrm{m}^{2}$ に特有なも のと思われる。本結節の頻度はJでは比較的低く、W及びNでは飛躍的に增加しているが、 これは大曰齒に拈ける人種差と本行した現像であると思われる（第 6 表）。

$\mathrm{m}^{1}$ では CARABELLI 結節は比較的少なく、その發達も弱い。多くは痕跡の程度で pit は ほとんどない。 $\mathrm{m}^{2}$ の場合と同樣にWに最も多く現われている（第 8 表）。

6. Protoconule. $\mathrm{m}^{2}$ では多くの場合 protoconule が認められるが、これは原始 的特徵と考吕られる。その頻度は 85〜90\%で 3 群ともほとんぞ變らない。

7. Metaconule. これも原始的特徽と考えられているものである。 $\mathrm{m}^{2}$ に括ける頻度 は protoconule よりも低く、いずれも $70 \%$ 臺で各群とも protoconule の頻度との間に 有意差が存在する。しかし群間の差は認められない。

$\mathrm{m}^{1}$ でも稀に metaconule の存在するものがあるが一般に弱く、その頻度も極めて低い。

8. 近心結節及び crista transversa. 近心溝の近心端又は近心邊緣隆線と paracone の 中心隆線との間に存在する小結節を近心結節と呼ぶことにする（第 7 圖 a)。これは paracone に附屬しているものと考㝋られ、Gigantopithecus の $\mathrm{M}^{2}$ に括ける“5th cusp” (KoEnIGSWALD, '52) に相當するものである。 $\mathrm{m}^{2}$ では多くの個體にこの結節が存在し、その 頻度は全數の約 $3 / 4$ 〜 $4 / 5$ である。又この結節が特に發達している個體では crista transversa の如きものが形成されて扣り、これら兩形質は密接な關係をもつているものと思われ る。

$\mathrm{m}^{1}$ に打ける近心結節は煩側郎ち paracone の方に寄つている場合が多く、その頻度は $50 \%$ わずかに越える程度で $\mathrm{m}^{2}$ より低い。近心結節に關して $\mathrm{m}^{2}, \mathrm{~m}^{1}$ 共に 3 群間の差はな W。

9. 斜走隆線。 $\mathrm{m}^{2}$ の斜走隆線は $\mathrm{M}^{1}$ に比してかなり明瞭である。一方 $\mathrm{m}^{1}$ ではほとん ぞ認められないが、 metacone 及び hypocone の分化に件つて弱い隆線の存在すること もある。本形質に關して 3 群の間に差はないようである。 
10. 煩側面の 浮彫像 (cingulum). 上顎 乳臼齒の 煩剈面には tuberculum molare が發達し、この部分から弱い隆起ないし皱璧が咬面に向つて伸び出すことがある。これは cingulum の痕跡と考兄られ、下顎齒の protostylid と同性質のものであろう。WEIDENREICH は Sinanthropus の研究に拈いてこれが stylar cusp の遺殘であるとした。

この結節は $\mathrm{m}^{2}$ においては J 18.8\%、W 15.5\%、N 15.8\% の頻度で認められるが、 $\mathrm{m}^{1}$ ではそれぞれ 29.4\%、32.4\%、30.6\%と約 2 倍に增加している。この形質に關して 3 群間に 差は認められない。

以上の觀察の結果、 $\mathrm{m}^{1}$ には一般に原始的特徵と考えられる形質が多く存在している。こ れに對して $\mathrm{m}^{2}$ ではしばしば指摘したよ5にかなり分化又は退化が進んでいるが、 $\mathrm{M}^{1}$ に比 較するとな㹉始的と思われる形質が多い。從つて少なくとも齒冠の形態に關する限り、 $\mathrm{m}^{1}$ $\rightarrow \mathrm{m}^{2} \rightarrow \mathrm{M}^{1}$ の方向に進む進化の系列が考光られる。

又更に上顎乳田齒と上顎小臼齒との間にも密接な關係が見出されるが、この點については 考察の章で論じたので省略する。

$\mathrm{J}, \mathrm{W}, \mathrm{N} 3$ 群の間には明膫な差の認められる形質もあり、然らざるものもあるが、これら の比較は第 5 篇にゆずりたい。

終りに、本研究にはエリザベス・サンダース・ホーム、文京區立第一幻稚園及び二葉保育 園の協力を頂き、又東大理學部人類學㸚室須田昭義助呚授の指導並びに清水正一博士の助力 を賜わつた。記して厚く御禮申し上げたい。

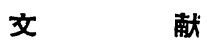

AвEL, W.: 1931. Kritische Untersuchungen über Australopithecus africanus Dart. Morph. Jahrb., 65: 539-640.

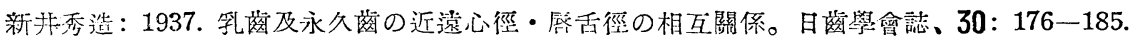

BLACK, G. V.: 1902. Descriptive anatomy of human teeth. Philadelphia.

DAHLBERG, AlBERT A.: 1949. The dentition of American Indian. The physical anthropology of the American Indian, pp. 138-176, The Viking Fund Inc.

- : 1950. The evolutionary significance of the protostylid. Am. J. Phys. Anthrop., n. s. 8: $15-24$.

DIETz, ViCTOR H.: 1944. A common dental morphotropic factor the CaraberLI cusp. J. Am. Dent. Assn., 31: 784-789.

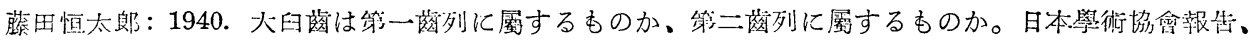

15: $117-121$.

— : 1949. 龂の解剖學。㷊京。

GoRJANOvić-KRAMBERger, K.: 1906. Der diluviale Mensch von Krapina in Kroatien. WALKHOFF's Studien über die Entwicklungsmechanik des Primatenskelets. 2. Lieferg. Wiesbaden.

Gregory, William K.: 1916. Studies on the evolution of the primates. Bull. Am. Mus. Nat. Hist., 35: 239-355.

- 1922 . The origin and evolution of the human dentition. Baltimore.

- : 1934. A half century of trituberculy, the COPE-OSBORN theory of dental evolution. 
Proc. Am. Phil. Soc., 73: 169-317.

Gregory, W. K. and MILO HellmaN: 1926. The dentition of Dryopithecus and the origin of man. Anthrop. Pap. Am. Mus. Nat. Hist., vol, 28, pt. 1.

埴原和郎： 1954 a. 同一個體におりる第 2 乳臼齔及び第 1 大臼菌苳冠形態の類似性について。日本人類 學會・日本民族學協會連合大會第 9 回紀事。

—： 1954 b. 日本人及び日米混血兒乳齒の研究、I. 乳切蓠について。人類學雜誌、63:168-185.

- : 1955. 同上. II. 乳犬齒について。人類學䌖誌。64:63-82.

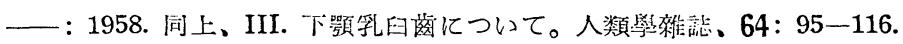

JONES, HECTOR G.: 1947. The primary dentition in Homo sapiens and the search for primitive features. Am. J. Phys. Anthrop., n. s. 5: 251-274.

Koenigswald, G. H. R. von: 1952. Gigantopithecus blacki von Koenigswald, a giant fossil hominoid from the Pleistocene of Southern China. Anthrop. Pap. Am. Mus. Nat. Hist., vol. 43 , pt. 4.

LE Gros Clark, W. E. and L. S. B. Leakey: 1951. The Miocene Hominoidea of East Africa. Fossil Mammals of Africa, No. 1. Brit. Mus. (Nat. Hist.)

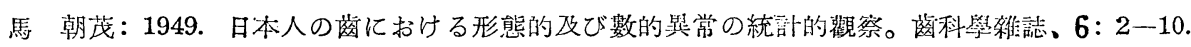

McCown, T. D. and Sir A. Kerth: 1949. The stone age of Mount Carmel, Vol. II. Oxford. MatThew, W. D.: 1915. Revision of the Lower Eocene primates. Bull. Am. Mus. Nat. Hist., 34: 429-483. (Cited by GREGory, '16.)

OsBorn, H. F.: 1907. Evolution of mammalian molar teeth to and from the triangular type. New York. (Cited by Gregory, '16.)

Pedersen, P. O.: 1949. The East Greenland Eskimo dentition. Medelelser om Gronland, vol. 142. Copenhagen.

清水正一：1955. 双生兒法による䔄冠形態の砰究。日本法整誌、9: 24-40.

VRam, Ugo G.: 1898. Studio sui denti molari umani. Atti Soc. Romana, Antrop., 5: 155-196. (Cited by WEIDENREICH, '45.)

WEIDENREICH, FraNZ: 1937. The dentition of Sinanthropus pekinensis: A comparative odontography of the hominids. Palaeont. Sinica, n. s. D, no. 1.

- : 1945. Giant early man from Java and South China. Anthrop. Pap. Am. Mus. Nat. Hist., vol. 40 , pt. 1.

WheEle, RUSSELL C.: 1950. A textbook of dental anatomy and physiology. 2nd ed. Philadelphia.

(可京大學理學部人類學教安) 


\section{Studies on the Deciduous Dentition of the Japanese and the Japanese-American Hybrids. \\ IV. Deciduous Upper Molars}

\section{KAZURŌ HANIHARA}

This article describes the deciduous upper molars and forms the fourth chapter of my work.

Most of the materials used were concerned with the same individuals as in the previous chapters, although a few more subjects have been included (Tab. 1). The latter were from three to six years of age.

The observations were made on tooth crowns only, as in the former chapters, because our materials were plaster casts from living subjects. The capital letters $\mathrm{J}, \mathrm{W}$ and $\mathrm{N}$ used in my descriptions are abbreviations for the three groups: Japanese, Japanese-American White hybrids and JapaneseAmerican Negro hybrids, respectively.

The results are briefly summarized as follows:

1. Mesio-distal diameter of crown: Sexual differences were not observed in $\mathrm{J}$ and $\mathrm{W}$ but are distinct in $\mathrm{N}$. In comparing the three groups, $\mathrm{N}$ has the largest value and there are no significant differences between $J$ and $W$. These facts have been observed in also the deciduous lower molars (Tabs. 2, 3 and 4).

2. Bucco-lingual diameter of crown: Sexual differences are recognized in $\mathrm{W}$ and $\mathrm{N}$. Among the three groups, $\mathrm{W}$ has the smallest value (Tabs. 2, 3 and 4 ).

3. Length-breadth index of crown: The bucco-lingual diameter of the deciduous upper molar is larger than the mesio-distal, so that the lengthbreadth index is over 100 . Sexual and inter-group differences are not observed but in $\mathrm{m}^{1}$, namely, $\mathrm{J}$ is significantly larger than $\mathrm{N}$. In general, this index is larger in $\mathrm{m}^{1}$ than in $\mathrm{m}^{2}$. This fact indicates that the former is relatively longer than the latter in the direction of the transverse axis. The same is true in the deciduous lower molars, provided that $m_{1}$ is relatively longer in the direction of the sagittal axis (Tabs. 2 and 3 ).

4. Differentiation of cusps: $\mathrm{m}^{2}$ is always four-cusped. Individuals in which the hypocone is well developed (" 4 " type of DAHLberG, '49, Fig. 3) occupy $3 / 4-4 / 5$ of the entire series. In our three groups, the frequency of " 4" type relatively increases in $\mathrm{W}$ but there is no significant difference between $\mathrm{J}$ and $\mathrm{N}$ ( Tab. 5). In $\mathrm{m}^{1}$, the differentiation of the two cusps, metacone and hypocone, is very weak, but occasionally, we can find indivi- 
duals in which these two cusps are relatively distinct. As a whole, degree of differentiation of the metacone is somewhat higher than that of the hypocone (Fig. 11). Table 7 shows frequencies of well developed cusps in $\mathrm{m}^{1}$. Those excluded from this table constitute a group of individuals in which the cusps are very faintly developed or show only a faint trace.

5. Carabelli's cusp: Frequencies of this cusp are very high in $\mathrm{m}^{2}$, above all, we can find many more pits than in the permanent upper molars. In three groups, this character is relatively rare in $\mathrm{J}$ but is common in $\mathrm{W}$ and $\mathrm{N}$. This seems to be a phenomenon parallel to the racial differences of the permanent dentition (Tab. 6). On the other hand, Carabelli's cusp in $\mathrm{m}^{1}$ is very rare and weak (Fig. 12). However, the tendency for this cusp to be found in relatively high frequency in $\mathrm{W}$ is also recognized in this tooth (Tab. 8).

6. Protoconule: In many cases the protoconule is found in $\mathrm{m}^{2}$. This tubercle is considered as a primitive character by many authors (Fig. 5). The frequency in $\mathrm{m}^{2}$ is $85-90 \%$ and there is no significant difference among our three groups.

7. Metaconule: This tubercle is also considered as a primitive character (Fig. 6). The frequency of $\mathrm{m}^{2}$ is a little over $70 \%$ in all three groups and this figure is significantly lower than that for the protoconule. The frequencies in $\mathrm{m}^{1}$ are much lower and the tubercle itself is weaker than in $\mathrm{m}^{2}$ (Fig. 13, b).

8. Mesial tubercle and crista transversa: There is a small tubercle which is located at the position of the fossa anterior or between the mesial marginal ridge and the central ridge of the paracone. This tubercle corresponds to the "5th cusp" (Konnigswald, '52) of Gigantopithecus which WeIdenkeich ('45) called a "flower-bud pattern" in the same specimen. I should like to refer to this formation as the "mesial tubercle". We can find many individuals with this tubercle and the frequencies are $3 / 4-4 / 5$ of the entire series of $\mathrm{m}^{2}$ (Fig. 7, a). In the individuals with a strongly developed mesial tubercle, we can recognize a formation which seems to be a trace of the crista transversa (Fig. 7, c). Hence, it may be considered that there is a close connection between the mesial tubercle and the crista transversa. Nevertheless the mesial tubercle in $\mathrm{m}^{1}$ is relatively infrequent, namely, in which the frequencies are a little over $50 \%$ in three groups. Inter-group differences are not found in regard to this character.

9. Crista obliqua: The crista obliqua in $\mathrm{m}^{2}$ is tolerably clearer than in $\mathrm{M}^{1}$, while it is very little developed in $\mathrm{m}^{1}$ (Figs. 8 and 13, a). WeIdenreich ('45) said that this ridge is much weaker in Gigantopithecus and Sinanthropus and in modern man than in the anthropoids. According to this opinion it is 
considered that the crista obliqua is more degenerated in $\mathrm{M}^{1}$ than $\mathrm{m}^{2}$, while it is not yet differentiated in $\mathrm{m}^{1}$. Differences in regard to this crista are not found among the three groups.

10. Relief on the buccal surface (cingulum): The tuberculum molare appears on the buccal surface of the deciduous upper molars (Fig. 10). In some cases, a slight ridge extends from this tubercle to the occlusal surface. It is considered that this ridge is homologous with the protostylid of the lower molars. WeIDEnReich ('37) stated that the same formation had been found in Sinanthropus and that this was a derivative of the stylar cusp (Fig. 16, b). The frequencies of the ridge in three groups, $\mathrm{J}, \mathrm{W}$ and $\mathrm{N}$, are $18.8 \%, 15.5 \%$ and $15.8 \%$ in $\mathrm{m}^{2}$, and $29.4 \%, 32.4 \%$ and $30.6 \%$ in $\mathrm{m}^{1}$, respectively. On the other hand, individuals with a ridge running along the mesial angle of the buccal surface are not rare. WeIDENREICH named the same character in the deciduous lower molars in Sinanthropus the "ascending portion of the cingulum", so that our case might be called the "descending portion of the cingulum" (Fig. 16, a). This character is frequently found in $\mathrm{m}^{1}$ but is relatively rare in $\mathrm{m}^{2}$.

The results above mentioned lead us to the opinion that, as compared with $\mathrm{m}^{2}$, the differentiation of the crown pattern is not so well developed as in $\mathrm{m}^{1}$ and the latter has many characters which may be considered as primitive. Furthermore, these are more or less differentiated or degenerate in $\mathrm{m}^{2}$. For instance, the lower degree of development of the metacone, hypocone, crista obliqua, etc. in $\mathrm{m}^{1}$ may be interpreted as a result of the retarded differentiation and relatively strong development of the tuberculum molare as an indication of primitiveness. Nevertheless, when we compare $\mathrm{m}^{2}$ with $\mathbf{M}^{1}$, it cannot be ignored that the former has more primitive characters than the latter.

With regard to the comparison of the three groups I will discuss these in more detail in the fifth or last chapter of this work. 